special reference to the bones. The surface structure of the teeth, their arrangement in the jaws, the number of carious teeth and the extent of caries in each, as well as the condition of the gums and the general physical state were noted at the beginning of the investigation and at each subsequent examination. The differences between the findings at the first and final inspections in each diet group were then compared.

This investigation has shown again that there is a definite direct association between the structure of the teeth and the amount of caries present in a mouth: this relationship was found in the case of both the original and newly erupted permanent teeth in the olive oil group. Although no definite evidence was obtained that diet had an effect upon the structure of the permanent teeth, there were indications that the addition of vitamin $\mathrm{D}$ during the period of development tends to improve the structure of the first permanent molars. On the other hand, it was proved conclusively that a high vitamin $\mathrm{D}$ intake before the full eruption of the permanent teeth significantly diminishes the incidence of caries in such teeth after eruption : this protective effect was especially striking in the case of the premolars and second permanent molars, which erupt later than the first permanent molars. As regards the deciduous teeth, only in the case of the youngest children could any effect of the additions to the diet be expected; evidence was obtained that caries was less progressive in the vitamin groups than in that receiving treacle.

It is of interest to note that although the incidence of fresh caries in the permanent teeth present at the beginning of the investigation was the same in the two control groups, yet the spread and degree of softening were significantly greater in the olive oil group : in the case of the deciduous teeth, however, there was a greater increase in the percentage of carious teeth in the treacle than in the olive oil group.

Summing up the results of these extensive experiments, it may be concluded that a relatively high intake of vitamin $\mathbf{D}$ can do much to diminish the incidence of caries if the vitamin is given during the period of development of the teeth : that a beneficial effect may be obtained if it is given at a fairly late stage of development; and that even when it is given after the eruption of the teeth, the onset and spread of caries are delayed.

\title{
Problems of Plantation Economy
}

IN choosing the subject of "Plantation Economy" 1 for his presidential address to Section $\mathrm{F}$ (Economics and Statistical Science) of the British Association, delivered at Blackpool on September 11, Dr. C. R. Fay rightly directed attention to a neglected corner of knowledge which has lessons of much interest to the sociologist as well as the economist, to the historian, the geographer and the administrator as well as the agriculturist. Dr. Fay was clearly inspired by a recent tour in the East, and dealt mainly with the tea plantations of India. He contented himself with a straightforward account of the industry, and refrained, perhaps wisely, from comment on the wider issues.

The Royal Commission on Labour in India (1931) pointed out the similarity between a plantation and a factory--both employing a considerable number of persons under the control of a manager. The chief difference is that the work in one case is essentially agricultural and is not concentrated in a large building. The analogy is important; until regulated by factory acts, 'exploitation' of labour too often characterized the growing manufacturing industry just as exploitation of labour-including slavery-characterized the early plantation industry. Tobacco in the south-eastern United States, and sugar in the West Indies a hundred or more years ago, ought to be thought of in comparison with the Lancashire cotton mills of the same period. It is scarcely possible to contemplate the modern world without a factory system, yet the corresponding plantation system is not only less important than formerly, but also may be described as 'suspect'. To-day, India, Further India and the East Indies are the home of the greatest plantation industries, tea and rubber, and this is considered by Dr. Fay to be due in considerable measure to Government opposition to the system in Africa. Dr. Fay quotes figures in his opening paragraph to show that, despite a relatively small area, plantation products (mainly tea) account for nearly a fifth by value of the agricultural exports of India. This statement has little meaning-what one would like to know is the relative productivity of a given area of land under plantation organization and under unregulated native cultivation, and the relative cost per unit of production, having due regard to quality. 
Since the bulk of the world's tea is produced in plantations, it will be of interest to detect the reasons for the persistence of plantation economy in the case of this commodity. In the first place, tea is in large demand among the white races, yet is the product of a tropical or sub-tropical shrub growing under conditions unsuited to white manual labour. Here is the essential basis for the old plantation industry in sugar, cotton, tobacco and indigo, and the modern industry in rubber. In the second place, rigid adherence to a daily timetable is essential-tea leaves must be plucked exactly when they are ready ; the 'flush' must be dealt with immediately at the factory, withering must go on until almost exactly 42 per cent of the moisture is lost-after about eighteen hours. This all means adequate organization and supervision, or the quality of the resulting tea will suffer. There would be no market for the output of a factory which did not maintain an even standard. So much so is this the case that most factories consider it unwise to use supplies from other than their own plantations. Herein lies an important difference from other plantation industriescotton can be bought according to quality from the small-holder; sugar cane can be brought to the sugar 'central' and does not deteriorate so rapidly. With tea the deterioration after plucking is so marked that 'lorry tea' (that is, brought in by the quickest method of transport) is regarded as superior.

Dr. Fay points out that, in the early European settlement of the New World, 'plantation' and 'colony' were virtually synonymous ; the plantation was the economic instrument whereby colonies were established. Conditions of life were difficult for employee and manager alike. To be sent to the plantations was equivalent to disciplinary banishment for the turbulent younger sons. The negro States and the West Indies owe their population-and many of their present-day problems-to the system. It is curious that the present home of the plantation-the East-was, with its existing large population, at this earlier date recognized as a field for trade rather than colonization. Thus India and the East Indies had trading posts and forts to guard them, but not plantations. Since tea and rubber planting began there much later, its history has been happier. The tea-gardens of Assam attracted to that pleasant province labourers from overcrowded Bihar who, after their term of work was finished, settled down to work the land under conditions far superior to those in their home areas. Four fifths of the people of Assam are 'foreigners' by birth or origin - the tea-gardens have enabled this important migration to take place and have done much to relieve one of the pressing population problems of India. To a less degree the rubber plantations of Malaya have had the same effect, with the difference that the Indian coolies have not been encouraged to settle. But rubber has given Malaya and the Dutch East Indies fine roads and railways and a vastly improved standard of living for the people.

The plantation system, under modern humane supervision, may thus confer great benefits on a world the agriculture of which is in a state of chaos. Not only may it provide diverse parts of the earth with commodities otherwise unobtainable - a good example is the highly organized banana industrybut it may also prove the way to development and settlement of tracts to which the individual settler without capital neither could nor would be attracted. Our economists and sociologists would be doing a great service by studying dispassionately the application of a modern plantation economy in Africa, Australia and other sparsely populated parts of the world.

\section{Dudley Stamp.}

\section{The Hexlet*}

$T \begin{aligned} & \text { OWEVER ill-assorted in girth three spheres } \\ & \text { may be }\end{aligned}$ Each one can kiss the other two and simultaneously A ring of six about them all kissing serially.

Though any necklet of graded beads May fit in general the she-sex,

This Hexlet of mine of novel design Caresses not one but three necks.

However it's worn it alters its grade To suit its tri-spherical prison,

Plays kiss-in-the-ring and merry-go-round Whilst hugging three necks with precision.

Like bubbles that blow and dwindle and go

It holds up to light-hearted derision

The terrible muddle mathematical fuddle Makes of the pure circumflex

And its pet aversion is the mental inversion That will have 'It's $1 / x$ '.

All saints and sages throughout the ages

From one doxy never have swerved,

To hold fast unto what in change changes not

And ferret out what is conserved.

Now these beads without flaw obey this first law For the aggregate sum of their bends.

As each in the tunnel slims through the funnel Its vis-à-vis grossly distends.

But the mean of the bends of each opposite pair Is the sum of the three of the thoroughfare.

Nov. 7, 1936.

FreDERICK SODDY.

*vide "The Kiss Precise" (NATURE, 137, 1021, June 20, 1936). 